\begin{tabular}{|c|c|c|}
\hline IK & $\begin{array}{c}\text { BIODIK: Jurnal IImiah Pendidikan Biologi } \\
\text { ISSN 2580-0922 (online), ISSN 2460-2612 (print) } \\
\text { Volume 6, Nomor 03, Tahun 2020, Hal. 312-318 } \\
\text { Available online at: } \\
\text { https://online-journal.unja.ac.id/biodik }\end{array}$ & BIODIK \\
\hline
\end{tabular}

Research Article OPEN ACCESS

\title{
Keterampilan Argumentasi Siswa Pada Materi Sistem Gerak SMA Negeri Kabupaten Sukabumi-Indonesia
}

(Student's Argumentation Skills on Motion Systems Material at SMA Negeri Sukabumi-Indonesia)

Yunita Rahayu*, Suhendar, Jujun Ratnasari

Universitas Muhammadiyah Sukabumi

JI. R. Syamsudin, S.H. No. 50, Kec. Cikole, Kota Sukabumi, 43113, Indonesia

${ }^{*}$ Corresponding Auther: yunitarhy0@gmail.com

\begin{tabular}{|c|c|}
\hline Informasi Artikel & ABSTRACT \\
\hline $\begin{array}{l}\text { Submit: } 21-05-2020 \\
\text { Diterima: } 15-08-2020 \\
\text { Dipublikasikan: } 05-09-2020\end{array}$ & $\begin{array}{l}\text { Argumentation skills are skills that can encourage students to be involved in providing } \\
\text { facts, data and theories that are appropriate to support claims against a problem. The } \\
\text { purpose of this study is to determine the profile of written argumentation skills of } \\
\text { senior high school (SMA) students on the motion system material that has been } \\
\text { learned by students. The method in this study uses a descriptive method with a } \\
\text { qualitative approach. The research subjects were students of grade XI of Sukabumi } \\
\text { Regency State High School. Samples were taken using a purposive sampling } \\
\text { technique with a total of } 36 \text { students, who had followed the motion system material. } \\
\text { The instrument used was in the form of problem descriptions to measure students' } \\
\text { argumentation skills with a total of } 10 \text { questions that referred to the criteria level and } \\
\text { the argumentation skills of the Toulmin Argumentation Pattern (TAP). The results } \\
\text { showed that the written argumentation skills of Grade XI students of the State Senior } \\
\text { High School in Sukabumi Regency in the academic year } 2019 / 2020 \text { were still in the } \\
\text { low category, this was indicated by the highest percentage results at level } 1 \text { namely } \\
38 \% \text { and level } 2 \text { at } 36 \% \text {. While the highest percentage based on indicator criteria is } \\
83 \% \text { on the claim indicator. Therefore the students 'written argumentation skills must } \\
\text { be improved by using methods, models and learning approaches that are able to } \\
\text { practice students' written argumentation skills. } \\
\text { Keywords: Written arqumentation skills, high school, motion system materials }\end{array}$ \\
\hline Penerbit & ABSTRAK \\
\hline $\begin{array}{l}\text { Program Studi Pendidikan } \\
\text { Biologi, Fakultas Keguruan dan } \\
\text { Ilmu Pendidikan, Universitas } \\
\text { Jambi }\end{array}$ & $\begin{array}{l}\text { Keterampilan argumentasi merupakan keterampilan yang dapat mendorong siswa } \\
\text { untuk terlibat dalam memberikan fakta, data dan teori yang sesuai untuk mendukung } \\
\text { klaim terhadap suatu permasalahan. Tujuan dari penelitian ini yaitu untuk } \\
\text { mengetahui profil keterampilan argumentasi tertulis siswa Sekola Menengah Atas } \\
\text { (SMA) pada materi sistem gerak yang sudah dipelajari oleh siswa. Metode dalam } \\
\text { penelitian ini menggunakan metode deskriptif dengan pendekatan kualitatif. Subjek } \\
\text { penelitian adalah siswa kelas XI Sekolah Menengah Atas Negeri Kabupaten } \\
\text { Sukabumi. Sampel diambil menggunakan teknik purposive sampling dengan jumlah } \\
36 \text { siswa, yang telah mengikuti materi sistem gerak. Instrumen yang digunakan } \\
\text { berupa soal uraian untuk mengukur keterampilan argumentasi siswa dengan jumlah } \\
10 \text { soal yang mengacu pada krteria level dan indikator keterampilan argumentasi } \\
\text { Toulmin Argumentation Pattern (TAP). Hasil penelitian menunjukkan bahwa } \\
\text { keterampilan argumentasi tertulis siswa kelas XI Sekolah Menengah Atas Negeri } \\
\text { Kabupaten Sukabumi tahun ajaran } 2019 / 2020 \text { masih dalam kategori rendah, hal } \\
\text { tersebut dtunjukan oleh hasil persentase tertinggi pada level } 1 \text { yaitu } 38 \% \text { dan level } 2 \\
\text { sebanyak } 36 \% \text {. Sedangkan persentase tertinggi berdasarkan kriteria indikator yaitu } \\
83 \% \text { pada indikator klaim. Maka dari itu keterampilan argumentasi tertulis siswa ini } \\
\text { harus ditingkatkan kembali dengan meggunakan metode, model dan pendekatan } \\
\text { pembelajaran yang mampu melatihkan keterampilan argumentasi tertuls siswa. }\end{array}$ \\
\hline & menengah atas, materi \\
\hline
\end{tabular}




\section{PENDAHULUAN}

Sistem pembelajaran yang baik merupakan sistem pembelajaran yang mengacu pada pembelajaran abad 21 yaitu kemampuan berpikir kritis, memecahkan masalah, berkolaborasi dan berkomunikasi (Pritsari 2016). Kemampuan tersebut dapat dilakukan melalui pembelajaran yang dipersiapkan dengan baik. Komponen utama dalam proses pembelajaran yaitu keterlibatan dalam berbagai aspek penting meliputi merumuskan pertanyaan, mendeskripsikan mekanisme dan membangun argumen. Salah satu komponen tersebut adalah siswa dituntut agar memiliki kemampuan argumetasi yang baik (Pritasari 2016).

Keterampilan argumentasi dapat melatih siswa untuk menggunakan kemampuan berpikirnya. Deane \& Song (dalam Pritasari, 2016) menjelaskan bahwa keterampilan argumentasi memiliki peran penting dalam meningkatkan pola berpikir kritis siswa sehingga dapat menambah pemahaman yang mendalam terhadap suatu gagasan maupun ide. Pembejaran sains menekankan siswa untuk memiliki kemampuan argumentasi yang baik (Christenson, N., Rundgren, S., \& Hoglund 2012). Selain itu, keterampilan argumentasi penting dikembangkan dalam pembelajaran sains untuk meningkatkan pemikiran dan pemahaman siswa terhadap materi yang dipelajari. Proses pembelajaran yang berbasis argumentasi dapat mendorong siswa untuk terlibat dalam memberikan fakta, data dan teori yang sesuai untuk mendukung klaim terhadap suatu permasalahan (Ginanjar, W. S., Setiya Utari 2015).

Argumentasi adalah proses diskursif untuk membuat klaim, memberikan bukti untuk mendukung klaim dan mengkritisi (Faize 2015). Berdasarkan model argumentasi Toulmin Argumentation Pattern (TAP) kualitas argumen terdiri dari enam komponen diantaranya: klaim (claim), data (data), penjamin (warrant), dukungan (backing), sanggahan (rebuttal), dan penguatan (qualifier) (Toulmin 1958, 2003). Argumentasi merupakan sebuah usaha untuk meyakinkan atau membuktikan kebenaran suatu pernyatan, pendapat, sikap atau keyakinan, dengan dibuktikan oleh fakta-fakta, sehingga mampu meyakinkan dan membuktikan bahwa pendapat tersebut dapat dikatakan benar atau tidak. Argumentasi bertujuan untuk mempengaruhi seorang pendengar untuk membenarkan pernyataan dan pendapat yang diajukan. Dengan mengemukakan sebuah argumentasi maka seorang pendengar akan menyetujui bahwa pendapat, keyakinan dan sikap pembicara tersebut benar.

Keterampilan argumentasi siswa sangat berpengaruh terhadap proses pembelajaran jika kemampuan siswa dalam berargumentasi masih rendah akan berdampak terhadap hasil belajarnya. Pemahaman seseorang terhadap konsep dan penalran dapat dilihat dari bagaimana orang tersebut dapat menuliskan 
argumentasinya dan menjelaskan dengan susunan kalimat yang jelas (Sudjana 2005). Maka dari itu penelitian ini perlu dilakukan untuk mengetahui sejauh mana keterampilan argumentasi tertulis siswa kelas XI di SMA Negeri Kabupaten Sukabumi. Hal ini dikarenakan sekolah tersebut belum pernah menerapkan pembelajaran yang dapat mengukur keterampilan argumenasi tertulis siswa. Selain itu, di Kabupaten Sukabumi belum ada penelitian mengenai profil keterampilan argumentasi tertulis siswa, sehingga, penelitian ini bertujuan untuk mengetahui profil keterampilan argumentasi siswa pada materi sistem gerak yang sudah dipelajari oleh siswa di SMA Negeri Kabupaten Sukabumi.

\section{METODE PENELITIAN}

Penelitian yang dilakukan menggunakan metode deskriptif dengan pendekatan kualitatif. Subjek yang digunakan pada penelitian ini yaitu siswa kelas XI SMA Negeri Kabupaten Sukabumi dengan jumlah 36 siswa, yang telah mengikuti materi sistem gerak. Penelitian ini dilaksanakan pada tanggal 18 November 2019. Prosedur pengambilan data dilakukan dengan memberikan soal berbentuk uraian yang berjumlah 10 soal dengan ketentuan waktu mengerjakan 45 menit. Instrumen yang digunakan yaitu berupa soal untuk mengukur keterampilan argumentasi siswa yang mengacu pada indikator keterampilan argumentasi Toulmin Argumentation Pattern (TAP). Rubrik skor tes tertulis keterampilan argumentasi diadaptasi dari Toulmin Argumentation Pattern (TAP) disajikan dalam tabel 1.

Tabel 1. Rubrik penilaian kemampuan argumentasi

\begin{tabular}{|c|c|}
\hline Level & Kriteria \\
\hline 1 & Argumentasi mengandung satu klaim melawan klaim lainnya. \\
\hline 2 & $\begin{array}{l}\text { Argumentasi memiliki argumen dari suatu klaim melawan klaim lain dengan data, } \\
\text { penjamin dan pendukung, tapi tidak mengandung sanggahan. }\end{array}$ \\
\hline 3 & $\begin{array}{l}\text { Argumentasi memiliki argumen dengan sebuah rangkaian klaim, data, penjamin dan } \\
\text { pendukung_serta sanggahan yang lemah. }\end{array}$ \\
\hline 4 & $\begin{array}{l}\text { Argumentasi menunjukkan argumen dengan sanggahan yang jelas dan mengandung } \\
\text { beberapa klaim }\end{array}$ \\
\hline 5 & $\begin{array}{l}\text { Argumentasi menyajikan argumen yang diperluas dengan lebih dari satu sanggahan } \\
\text { yang jelas. }\end{array}$ \\
\hline
\end{tabular}

\section{HASIL DAN PEMBAHASAN}

Argumentasi adalah proses diskursif untuk membuat klaim, memberikan bukti untuk mendukung klaim dan mengkritisi alternatif (Faize 2015). Proses pembelajaran yang berbasis argumentasi dapat mendorong siswa untuk terlibat dalam memberikan fakta, data dan teori yang sesuai untuk mendukung klaim terhadap suatu permasalahan (Ginanjar, W. S., Setiya Utari 2015). Dalam penelitian ini keterampilan argumentasi siswa yang diukur yaitu keterampilan argumentasi tertulis. Hasil penelitian keterampilan argumentasi siswa berdasarkan kriteria level argumentasi Toulmin Argumentation Pattern (TAP) disajikan dalam grafik yang dapat dilihat pada gambar 1. 


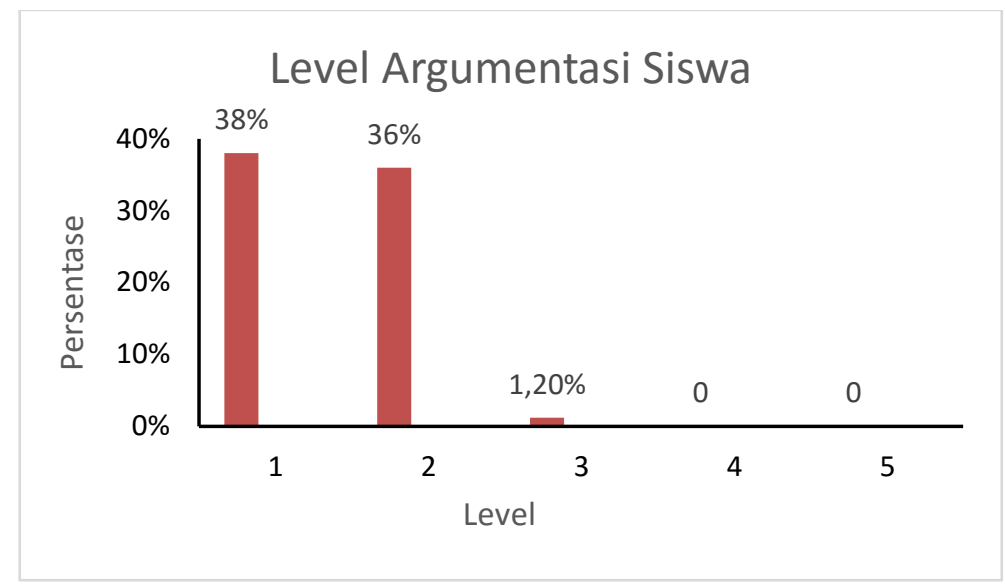

Gambar 1: Persentase level keterampilan argumentasi siswa

Berdasarkan grafik tersebut persentase level argumentasi siswa pada level 1 $(38 \%)$, pada level $2(36 \%)$, pada level $3(1,2 \%)$ sedangkan pada level 4 dan $5(0 \%)$, untuk 25\% lainnya berada di level 0 karena siswa memberikan jawaban klaim yang tidak tepat, namun ada juga siswa yang tidak mengisi jawabannya. Hasil penelitian menunjukan bahwa rata-rata level argumentasi siswa masih rendah, hal tersebut ditunjukkan dengan besarnya persentasi terbanyak pada level 1 yaitu $38 \%$. Jawaban siswa pada level 1 hanya mengandung satu klaim yang melawan klaim lainnya. Persentase kemampuan argumentasi berdasarkan indikator disajikan dalam grafik pada gambar 2.

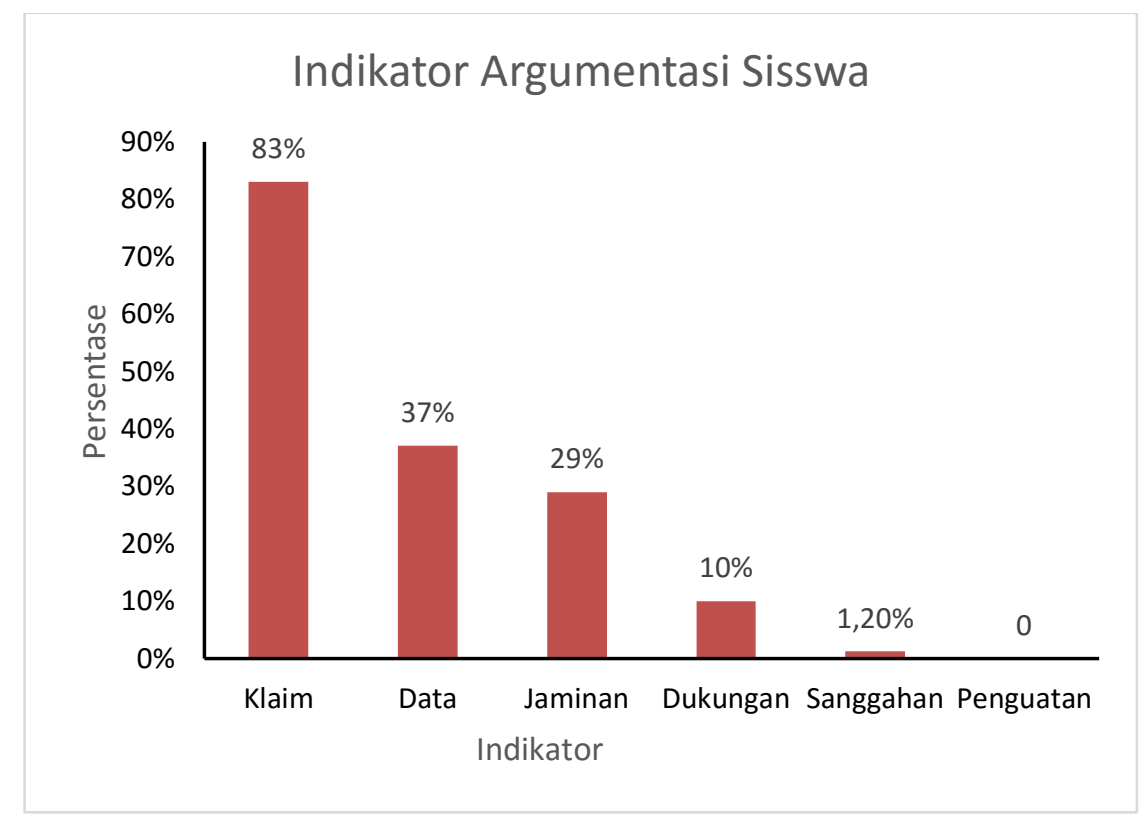

Gambar 2 : Persentase indikator dari setiap level argumentasi siswa

Data hasil penelitian pada gambar grafik diatas menunjukkan bahwa hasil persentase keterampilan argumentasi siswa berdasarkan indikator argumentasi yaitu 83\% siswa dapat menyertakan klaim (claim) di dalam jawabannya, 37\% jawaban 
siswa sudah mengandung data (data), 29\% penjamin (warrant), 10\% dukungan (backing), indikator sanggahan (rebuttal) hanya 1,2\% dan $0 \%$ pada indikator penguatan (qualifier) hal tersebut disebabkan karena penguatan merupakan bagian dari kriteria pada level 4 dan 5 dilihat dari grafik (Gambar 1) persentase level 4 dan 5 $(0 \%)$ sehingga tidak terdapat jawaban siswa yang menyertakan kalimat penguatan. Dengan demikian level argumentasi menunjukkan bahwa semakin tinggi level argumentasi siswa maka akan semakin kompleks indikator yang terkandung di dalam jawaban siswa.

Kriteria level argumentasi menurut Erduran et al., (2004) dapat menilai kualitas argumentasi seseorang, terdapat kriteri level 1-5. Semakin tinggi level argumentasi seseorang, maka argumen yang diemukakannya akan semakin kompleks dan luas. Berdasarkan hasil penelitian persentase tertinggi level argumentasi siswa yaitu pada level 1 sebesar 38\% jawaban siswa hanya mengandung klaim saja, namun klaim tersebut sudah di pastikan benar. Pada level 1 jawaban siswa tidak me.ngandung data, jaminan, dukungan, sanggahan atau penguatan pada klaim yang dipilih siswa pada jawabannya (Erduran, S., Simon, S., \& Osborne 2004). Sesuai dengan pernyataan Noviyanti et al,. (2019), pada level 1 argumentasi siswa belum bisa diberdayakan yang berarti termasuk kategori level argumentasi yang sangat lemah.

Persentase ke dua level argumentasi siswa yaitu pada level 2 sebesar 36\% jawaban siswa sudah mengandung data, jaminan dan dukungan dari klaim yang dipilih siswa. Hal tersebut sesuai dengan pernyataan Erduran et al,. (2004) yang menyatakan bahwa argumen memiliki lebih dari satu klaim yang melawan klaim lainnya dengan data, penjamin atau pendukung, namun tidak mengandung sanggahan. Dari data yang diperoleh rata-rata jawaban siswa pada level 2 lebih banyak mengandung data sebesar $37 \%$ dan jaminan $29 \%$ sedangkan dukangan hanya terdapat $10 \%$ dari jawaban siswa. Berkaitan dengan hal tersebut Bell dan lin (dalam Suraya, 2018) menyatakan bahwa secara umum jaminan digunakan oleh siswa untuk mendukung klaim yang dipilihnya tidak menyertakan jawaban dengan dukungan, sebab indikator data serta jaminan sangat berkaitan. Persentase indikator data menunjukkan persentase yang lebih besar daripada jaminan dan dukungan karena data dapat bersifat nyata dan sesuai fakta yang terjadi sehingga siswa mudah berpikir untuk menjawab agar dapat mendukungan klaim dari jawabannya. Perlu adanya pengembangan terhadap keterampilan argumentasi siswa pada level 2 karena pada level ini argumen terbukti masih lemah sebab jawaban belum mengandung sanggahan (Noviyanti Ika, N., Rosyadah Mukti, W., Dahlia Yuliskurniawati, I., Mahanal, S., \& Zubaidah 2019).

Persentase ke tiga level argumentasi siswa yaitu pada level 3 sebesar 1,2\% pada level ini jawaban siswa sudah mengandung data, jaminan, dukungan dan sanggahan, akan tetapi sanggahan yang terdapat pada jawaban siswa merupakan sanggahan yang lemah. Hal tersebut sesuai dengan pernyataan Erduran et al,. (2004) yang menyatakan bahwa argumen memiliki suatu rangkaian klaim, data, penjamin atau pendukung serta sanggahan yang lemah. Sanggahan yang lemah merupakan sanggahan yang digunakan tanpa menyertakan bukti (Demircioglu, T., \& 
Ucar 2015). Keterampilan argumentasi siswa pada level 3 dapat dikatakan cukup akan tetapi masih perlu dikembangkan lagi.

Persentase level argumentasi siswa terendah yaitu pada level 4 dan 5 sebesar 0\%. Pada level 4 argumen menunjukan argumen yang mengandung sanggahan yang jelas dan mengandung beberapa klaim (Erduran, S., Simon, S., \& Osborne 2004). Sedangkan level 5 argumen mengandung argumen yang kompleks serta menggandung lebih dari satu sanggahan atau penguatan (Eduran et al,. 2004). Sesuai dengan peneliian fitriyanti (2017) siswa pada level ini belum bisa menyanggah sebuah pernyataan yang mereka anggap salah dan belum bisa memberikan alasan terhadap pernyataan yang disanggahnya. Berdasarkan hasil penelitian tidak terdapat satupun siswa yang menjawab sampai di level 4 dan 5 artinya siswa belum memiliki argumen yang luas dan sanggahan yang berutun (Suraya, 2018).

Berdasarkan hasil penelitian menunjukan bahwa kualitas argumentasi siswa kelas XI di SMA Negeri Kabupaten Sukabumi masih rendah kebanyakan siswa masih berada di level 1 dengan persentase terbanyak yaitu $38 \%$, sehingga perlu adanya pengembangan lebih lanjut terkait keterampilan argumentasi siswa tersebut. Rendahnya keterampilan argumentasi siswa disebabkan kurangnya pemahaman siswa terhadap konsep dan teori dari materi sistem gerak yang sudah dipelajari. Selain itu siswa tidak terbiasa dilatih untuk berargumen, karena selama pemebelajaran siswa tidak difasilitasi dalam berargumen secara langsung maupun tertulis, sehingga siswa belum terbiasa mengisi soal tes argumentasi. Sesuai dengan teori yang dikemukakan Phillips dan Panuel (dalam Pritasari, 2016), bahwa jika siswa tidak terlatih berargumen maka siswa tidak akan mampu merumuskan pertanyaan dan mendeskripsikan mekanisme, sedangkan hal tersebut merupakan salah satu komponen utama dalam proses pembelajaran untuk membangun argumen siswa yang baik. Berdasarkan hasil penelitian (Ch, Ida F., \& Gusniarti 2014) kemampuan argumentasi siswa dapat meningkat seiring berjalannya prses pembelajaran berlangsung. Kemampuan agumentasi dalam pembelajaran sains berkitan erat dengan aktifitas penyelidikan (inqury) (Ch, Ida F., \& Gusniarti 2014). Maka dari itu keterampilan argumentasi tertulis siswa ini harus ditingkatkan kembali dengan meggunakan metode, model dan pendekatan pembelajaran yang mampu melatihkan keterampilan argumentasi tertuls siswa.

\section{KESIMPULAN}

Berdasarkan hasil penelitian yang telah dilakukan, keterampilan argumentasi tertulis siswa kelas XI SMA Negeri Kabupaten Sukabumi tahun ajaran 2019/2020 menunjukkan kualitas argumentasi tertulis siswa masih dalam kategori rendah karena pemebelajaran dikelas belum memfasilitasi siswa dalam berargumen secara langsung maupun tertulis, sehingga siswa belum terbiasa mengisi soal tes argumentasi. Maka dari itu keterampilan argumentasi tertulis siswa ini harus ditingkatkan kembali dengan meggunakan metode, model dan pendekatan pembelajaran yang mampu melatihkan keterampilan argumentasi tertuls siswa. 


\section{UCAPAN TERIMA KASIH}

Ucapan terimakasih saya sampaikan kepada berbagai pihak yaitu dosen pembimbing, guru-guru beserta siswa/siswi di salah satu SMA Kabupaten Sukabumi, kedua orang tua, dan teman-teman seperjuangan yang telah membantu dan membimbing dalam pelaksanaan penelitian dan penyusunan jurnal ini.

\section{DAFTAR PUSTAKA}

Ch, Ida F., \& Gusniarti, W. F. (2014). "No TitleProfil Keterampilan Argumentasi Siswa Pada Konsep Koloid Yang Dikembangkan Melalui Pembelajaran Inkuiri Argumentatif." Jurnal Edusains 4(1):32-40.

Christenson, N., Rundgren, S., \& Hoglund, H. (2012). "Using the SEE-SEP Model to Analyze Upper Secondary Student's Use of Supporting Reason in Arguing Sosioscientific Issues." Journal Science Education Technology 342-52.

Demircioglu, T., \& Ucar, S. (2015). "Nolnvestigating the Effect of Argument-Driven Inquiry in Laboratory Instruction Title." Educational Sciences 15(1):267-83.

Erduran, S., Simon, S., \& Osborne, J. (2004). "Tapping into Argumentation: Developments in the Application of Toulmin's Argument Pattern for Studying Science Discourseo Title." Science Education, 88(6).

Erduran, Sibel, Shirley Simon, and Jonathan Osborne. (2004). "TAPping into Argumentation: Developments in the Application of Toulmin's Argument Pattern for Studying Science Discourse." Science Education 88(6):915-33.

Faize, Fayyaz Ahmad. (2015). "Introducing Argumentation at Higher Education in Pakistan A New Paradigm of Teaching Ethic Based Topics." 9(1):8-13.

Fitriyati. (2018). Profil Kemampuan Argumentasi Siswa SMP Melalui TAP (Toulmin's Argumenttion Pattern) Pada Konsep Pemanasan Global. Skripsi: Universitas Muhammadiyah Sukabumi.

Ginanjar, W. S., Setiya Utari, \&. Muslim. (2015). "Penerapan Model Argument-Driven Inquiry Dalam Pembelajaran IPA Untuk Meningkatkan Kemampuan Argumentasi IImiah Siswa SMP." Jurnal Pengajaran MIPA 20(1):32-37.

Noviyanti Ika, N., Rosyadah Mukti, W., Dahlia Yuliskurniawati, I., Mahanal, S., \& Zubaidah, S. (2019). "Students' Scientific Argumentation Skills Based on Differences in Academic Ability." Journal of Physics: Conference Series 1241.

Sudjana. (2005). "Penilaian Hasi Proser Belajar Mengajar." Bandung: Remaja Rosdakarya.

Suraya. (2018). Keterampilan Argumentasi IImiah Dan Berpikir Kritis Melalui Metode Debat Pada Materi Keanekaragaman Hayati Siswa Kelas X Di Man 1 Natuna Kepulauan Riau. Skripsi: Universitas Muhammadiyah Pontianak.

Toulmin, S. E. (1958). "The Uses of Argument." C. Cambridge University Press, Ed.

Toulmin, S. E. (2003). "The Uses of Argument: Updated Edition." 